University of Vermont

UVM ScholarWorks

Rubenstein School of Environment and Natural Rubenstein School of Environment and Natural Resources Faculty Publications

$4-1-2018$

\title{
Nudging pro-environmental behavior: evidence and opportunities
}

\author{
Hilary Byerly \\ University of Vermont \\ Andrew Balmford \\ University of Cambridge \\ Paul J. Ferraro \\ Johns Hopkins Carey Business School \\ Courtney Hammond Wagner \\ University of Vermont \\ Elizabeth Palchak \\ University of Vermont
}

See next page for additional authors

Follow this and additional works at: https://scholarworks.uvm.edu/rsfac

Part of the Climate Commons

\section{Recommended Citation}

Byerly H, Balmford A, Ferraro PJ, Hammond Wagner C, Palchak E, Polasky S, Ricketts TH, Schwartz AJ, Fisher B. Nudging pro-environmental behavior: evidence and opportunities. Frontiers in Ecology and the Environment. 2018 Apr;16(3):159-68.

This Article is brought to you for free and open access by the Rubenstein School of Environment and Natural Resources at UVM ScholarWorks. It has been accepted for inclusion in Rubenstein School of Environment and Natural Resources Faculty Publications by an authorized administrator of UVM ScholarWorks. For more information, please contact scholarworks@uvm.edu. 


\section{Authors}

Hilary Byerly, Andrew Balmford, Paul J. Ferraro, Courtney Hammond Wagner, Elizabeth Palchak, Stephen Polasky, Taylor H. Ricketts, Aaron J. Schwartz, and Brendan Fisher 


\section{H Byerly et al. - Supporting Information}

\section{WebTable 1. Domain-specific terms used in literature search}

\begin{tabular}{ll}
\hline Domain & Search terms \\
\hline Family & $\begin{array}{l}\text { birth + control / spacing; child; contraception; family + planning; fertility; } \\
\text { pregnancy }\end{array}$ \\
\hline Land & $\begin{array}{l}\text { agriculture; conservation + soil / water; farm; land + "best management practices" } \\
\text { / conservation / management / owner / use }\end{array}$ \\
\hline Meat & diet; meat; vegetarian \\
\hline Transportation & transport; travel \\
\hline Waste & consumption; waste + food / paper / plastic / prevention / production / reduction \\
\hline Water & water + conservation / household / residential / utility \\
\hline
\end{tabular}

Words separated by a slash (/) were used separately in combination with the word preceding the plus sign (+). For example, the words "birth" AND "control" were searched together, and then "birth" AND "spacing" were searched together. A semicolon indicates a separate search. 


\section{H Byerly et al. - Supporting Information}

\section{WebTable 2. Studies included in the review}

\begin{tabular}{|c|c|c|c|c|c|c|c|c|c|}
\hline Study & Domain & Behavior & Sampled population & $\begin{array}{l}\text { Sample } \\
\text { size }\end{array}$ & Setting & Measure & Target & $\begin{array}{l}\text { Intervention } \\
\text { specified }\end{array}$ & $\begin{array}{l}\text { Intervention } \\
\text { significant? }\end{array}$ \\
\hline Ahmed et al. (2015) & Family planning & Reduce fertility rate & Women and girls & 4083 & Field & Observed & Education & Training & Yes \\
\hline Ahmed et al. (2015) & Family planning & $\begin{array}{l}\text { Use contraception } \\
\text { Contribute resources to land }\end{array}$ & Women and girls & 4083 & Field & Reported & Education & Training & Yes \\
\hline Andrews et al. (2013) & Land management & conservation & Farmers & 1537 & Field & Observed & Salience & Framing & No \\
\hline Ashraf et al. (2014) & Family planning & Reduce fertility rate & Women and girls & 706 & Field & Observed & Norms & Presence of husband & Yes \\
\hline Ashraf et al. (2014) & Family planning & Use contraception & Women and girls & 706 & Field & Observed & Norms & Presence of husband & Yes \\
\hline Baca-Motes et al. (2013) & Water use & Reuse hotel towels & Hotel guests & 2416 & Field & Observed & Commitments & Combo & Yes \\
\hline Baca-Motes et al. (2013) & Water use & Reuse hotel towels & Hotel guests & 2416 & Field & Observed & Commitments & Goal-setting & Yes \\
\hline Baca-Motes et al. (2013) & Water use & Reuse hotel towels & Hotel guests & 2416 & Field & Observed & Salience & Identity & No \\
\hline Bachman and Katzev (1982) & Transportation choices & Use public transportation & Drivers & 75 & Field & Observed & Commitments & Goal-setting & Yes \\
\hline Bachman and Katzev (1982) & Transportation choices & Use public transportation & Drivers & 75 & Field & Observed & Commitments & Goal-setting & Yes \\
\hline Bachman and Katzev (1982) & Transportation choices & Use public transportation & Drivers & 75 & Field & Observed & Financial & Non-monetary & Yes \\
\hline Bachman and Katzev (1982) & Transportation choices & Use public transportation & Drivers & 75 & Field & Observed & Financial & Non-monetary & Yes \\
\hline Bachman and Katzev (1982) & Transportation choices & Use public transportation & Drivers & 75 & Field & Observed & Financial & Non-monetary & Yes \\
\hline Bachman and Katzev (1982) & Transportation choices & Use public transportation & Drivers & 75 & Field & Observed & Financial & $\begin{array}{l}\text { Non-monetary } \\
\text { Implementation }\end{array}$ & Yes \\
\hline Bamberg (2002) & Transportation choices & Use public transportation & Undergraduates & 90 & Field & Observed & Commitments & intentions & Yes \\
\hline Bamberg (2006) & Transportation choices & Use public transportation & Drivers & 169 & Field & Reported & Financial & Non-monetary & Yes \\
\hline Bandiera et al. (2012) & Family planning & Reduce sexual activity & Women and girls & 4888 & Field & Reported & Education & Training & Yes \\
\hline Bandiera et al. (2012) & Family planning & Use contraception & Women and girls & 4888 & Field & Reported & Education & Training & Yes \\
\hline Bandiera et al. (2015) & Family planning & Reduce fertility rate & Women and girls & 4888 & Field & Observed & Education & Training & Yes \\
\hline Bashour et al. (2008) & Family planning & Use contraception & Women and girls & 876 & Field & Reported & Education & How-to tips & No \\
\hline Beale and Bonsall (2007) & Transportation choices & Use public transportation & Drivers & 205 & Field & Reported & Education & Data (general) & No \\
\hline Beale and Bonsall (2007) & Transportation choices & Use public transportation & Drivers & 71 & Field & Reported & Norms & Descriptive & No \\
\hline Beale and Bonsall (2007) & Transportation choices & Use public transportation & Drivers & 71 & Field & Reported & Financial & Non-monetary & No \\
\hline Bolderdijk et al. (2013) & Transportation choices & $\begin{array}{l}\text { Improve driving efficiency } \\
\text { Participate in water conservation }\end{array}$ & Drivers & 23 & Field & Observed & Salience & Framing & Yes \\
\hline Brent et al. (2015) & Water use & programs & Households & 2380 & Field & Observed & Norms & Aligned & No \\
\hline Brent et al. (2015) & Water use & $\begin{array}{l}\text { Reduce water use } \\
\text { Participate in water conservation }\end{array}$ & Households & 2380 & Field & Observed & Norms & Aligned & No \\
\hline Brent et al. (2015) & Water use & programs & Households & 1889 & Field & Observed & Norms & Aligned & Yes \\
\hline Brent et al. (2015) & Water use & $\begin{array}{l}\text { Reduce water use } \\
\text { Participate in water conservation }\end{array}$ & Households & 1889 & Field & Observed & Norms & Aligned & Yes \\
\hline Brent et al. (2015) & Water use & programs & Households & 3092 & Field & Observed & Norms & Aligned & Yes \\
\hline Brent et al. (2015) & Water use & Reduce water use & Households & 3092 & Field & Observed & Norms & Aligned & Yes \\
\hline $\begin{array}{l}\text { Campbell-Arvai and Arvai } \\
\text { (2015) }\end{array}$ & Meat consumption & Eat vegetarian & Undergraduates & 160 & Field & Observed & Education & $\begin{array}{l}\text { Environmental } \\
\text { impact }\end{array}$ & No \\
\hline $\begin{array}{l}\text { Campbell-Arvai and Arvai } \\
\text { (2015) }\end{array}$ & Meat consumption & Eat vegetarian & Undergraduates & 160 & Field & Observed & Defaults & $\begin{array}{l}\text { Opt-out } \\
\text { Environmental }\end{array}$ & Yes \\
\hline Campbell-Arvai et al. (2014) & Meat consumption & Eat vegetarian & Undergraduates & 320 & Field & Observed & Education & impact & No \\
\hline Campbell-Arvai et al. (2014) & Meat consumption & Eat vegetarian & Undergraduates & 320 & Field & Observed & Defaults & Opt-out & Yes \\
\hline Chong et al. (2013) & Family planning & Use contraception & High-school students & 3358 & Field & Observed & Education & Training & Yes \\
\hline Chong et al. (2013) & Family planning & Reduce sexual activity & High-school students & 3857 & Field & Reported & Education & Training & No \\
\hline Chong et al. (2013) & Family planning & Reduce fertility rate & High-school students & 4252 & Field & Reported & Education & Training & No \\
\hline Cobern et al. (1995) & Land management & Adopt conservation practices & Households & 120 & Field & Observed & Commitments & Goal-setting & No \\
\hline
\end{tabular}




\begin{tabular}{|c|c|c|c|c|c|c|c|c|c|}
\hline Study & Domain & Behavior & Sampled population & $\begin{array}{l}\text { Sample } \\
\text { size }\end{array}$ & Setting & Measure & Target & $\begin{array}{l}\text { Intervention } \\
\text { specified }\end{array}$ & $\begin{array}{l}\text { Intervention } \\
\text { significant? }\end{array}$ \\
\hline Cobern et al. (1995) & Land management & Adopt conservation practices & Households & 120 & Field & Observed & Commitments & Public & Yes \\
\hline Datta et al. (2015) & Water use & Reduce water use & Households & 5626 & Field & Observed & Norms & Descriptive & No \\
\hline Datta et al. (2015) & Water use & Reduce water use & Households & 5626 & Field & Observed & Norms & Descriptive & Yes \\
\hline Datta et al. (2015) & Water use & Reduce water use & Households & 5626 & Field & Observed & Commitments & Goal-setting & Yes \\
\hline de Groot et al. (2013) & Waste production & Reduce plastic waste & Shoppers & 200 & Field & Observed & Norms & Aligned & Yes \\
\hline de Groot et al. (2013) & Waste production & Reduce plastic waste & Shoppers & 200 & Field & Observed & Norms & Injunctive & Yes \\
\hline de Groot et al. (2013) & Waste production & Reduce plastic waste & Shoppers & 200 & Field & Observed & Norms & Personal & Yes \\
\hline de Young et al. (1993) & Waste production & Reduce plastic waste & Households & 103 & Field & Reported & Education & Data (general) & Yes \\
\hline de Young et al. (1993) & Waste production & Reduce plastic waste & Households & 103 & Field & Reported & Education & Data (general) & Yes \\
\hline de Young et al. (1993) & Waste production & Reduce plastic waste & Households & 103 & Field & Reported & Education & Data (general) & Yes \\
\hline Desai and Tarozzi (2011) & Family planning & Use contraception & Women and girls & 6275 & Field & Reported & Financial & Combo & No \\
\hline Desai and Tarozzi (2011) & Family planning & Use contraception & Women and girls & 6275 & Field & Reported & Financial & Monetary & No \\
\hline Desai and Tarozzi (2011) & Family planning & Use contraception & Women and girls & 6275 & Field & Reported & Education & Training & No \\
\hline Dickerson et al. (1992) & Water use & Reduce water use & Women and girls & 80 & Field & Observed & Commitments & Combo & Yes \\
\hline Dickerson et al. (1992) & Water use & Reduce water use & Undergraduates & 80 & Field & Observed & Commitments & Combo & Yes \\
\hline Dickerson et al. (1992) & Water use & Reduce water use & Women and girls & 80 & Field & Observed & Commitments & Public & No \\
\hline Dickerson et al. (1992) & Water use & Reduce water use & Undergraduates & 80 & Field & Observed & Commitments & Public & Yes \\
\hline Dickerson et al. (1992) & Water use & Reduce water use & Women and girls & 80 & Field & Observed & Salience & Reminder & No \\
\hline Dickerson et al. (1992) & Water use & Reduce water use & Undergraduates & 80 & Field & Observed & Salience & Reminder & Yes \\
\hline Egebark and Ekstrom (2016) & Waste production & Reduce paper waste & University employees & 1170 & Field & Observed & Norms & Injunctive & No \\
\hline Egebark and Ekstrom (2016) & Waste production & Reduce paper waste & University employees & 1170 & Field & Observed & Defaults & $\begin{array}{l}\text { Opt-out } \\
\text { Implementation }\end{array}$ & Yes \\
\hline Eriksson et al. (2008) & Transportation choices & Reduce driving & Drivers & 51 & Field & Reported & Commitments & intentions & No \\
\hline Ferraro and Price (2013) & Water use & Reduce water use & Households & 106669 & Field & Observed & Norms & Aligned & Yes \\
\hline Ferraro and Price (2013) & Water use & Reduce water use & Households & 106669 & Field & Observed & Education & How-to tips & Yes \\
\hline Ferraro and Price (2013) & Water use & Reduce water use & Households & 106669 & Field & Observed & Norms & Injunctive & Yes \\
\hline Fielding et al. (2013) & Water use & Reduce water use & Households & 183 & Field & Observed & Norms & Descriptive & Yes \\
\hline Fielding et al. (2013) & Water use & Reduce water use & Households & 183 & Field & Observed & Education & Feedback (personal) & Yes \\
\hline Fielding et al. (2013) & Water use & Reduce water use & Households & 183 & Field & Observed & Education & How-to tips & Yes \\
\hline Geller et al. (1983) & Water use & Reduce water use & Households & 129 & Field & Observed & Education & Feedback (personal) & No \\
\hline Geller et al. (1983) & Water use & Reduce water use & Households & 129 & Field & Observed & Education & How-to tips & No \\
\hline Geller et al. (1983) & Water use & Reduce water use & Households & 129 & Field & Observed & Financial & Non-monetary & Yes \\
\hline Goldstein et al. (2008) & Water use & Reuse hotel towels & Hotel guests & 1058 & Field & Observed & Norms & Aligned & Yes \\
\hline Goldstein et al. (2008) & Water use & Reuse hotel towels & Hotel guests & 1585 & Field & Observed & Norms & Descriptive & Yes \\
\hline Goldstein et al. (2008) & Water use & Reuse hotel towels & Hotel guests & 1585 & Field & Observed & Norms & Descriptive & Yes \\
\hline Goldstein et al. (2008) & Water use & Reuse hotel towels & Hotel guests & 1585 & Field & Observed & Norms & Descriptive & Yes \\
\hline Goldstein et al. (2008) & Water use & Reuse hotel towels & Hotel guests & 1585 & Field & Observed & Norms & Descriptive & Yes \\
\hline Goldstein et al. (2011) & Water use & Reuse hotel towels & Hotel guests & 634 & Field & Observed & Financial & Charitable donation & No \\
\hline Goldstein et al. (2011) & Water use & Reuse hotel towels & Hotel guests & 634 & Field & Observed & Norms & Reciprocation & Yes \\
\hline Hamann et al. (2015) & Waste production & Reduce paper waste & Households & 383 & Field & Observed & Norms & Descriptive & No \\
\hline Hamann et al. (2015) & Waste production & Reduce paper waste & Households & 383 & Field & Observed & Salience & Framing & Yes \\
\hline Hamann et al. (2015) & Waste production & Reduce paper waste & Households & 383 & Field & Observed & Norms & Injunctive & Yes \\
\hline Hou et al. (2010) & Family planning & Use contraception & Women and girls & 73 & Field & Observed & Salience & Reminder & No \\
\hline Jakobsson et al. (2002) & Transportation choices & Reduce driving & Drivers & 80 & Field & Reported & Financial & Monetary & No \\
\hline Jakobsson et al. (2002) & Transportation choices & Reduce driving & Drivers & 80 & Field & Reported & Financial & Monetary & No \\
\hline Jakobsson et al. (2002) & Transportation choices & Reduce driving & Drivers & 80 & Field & Reported & Commitments & $\begin{array}{l}\text { Implementation } \\
\text { intentions } \\
\text { Implementation }\end{array}$ & No \\
\hline Jakobsson et al. (2002) & Transportation choices & Reduce driving & Drivers & 80 & Field & Reported & Commitments & intentions & No \\
\hline Jayachandran et al. (2016) & Land management & Contribute resources to land & Households & 1099 & Field & Observed & Financial & Monetary & Yes \\
\hline
\end{tabular}




\begin{tabular}{|c|c|c|c|c|c|c|c|c|c|}
\hline Study & Domain & Behavior & Sampled population & $\begin{array}{l}\text { Sample } \\
\text { size }\end{array}$ & Setting & Measure & Target & $\begin{array}{l}\text { Intervention } \\
\text { specified }\end{array}$ & $\begin{array}{l}\text { Inter } \\
\text { signi }\end{array}$ \\
\hline & & conservation & & & & & & & \\
\hline $\begin{array}{l}\text { Kallbekken and Saelen } \\
\text { (2013) }\end{array}$ & Waste production & Reduce food waste & Hotel guests & 52 & Field & Observed & Norms & Descriptive & Yes \\
\hline Kallbekken and Saelen & Waste production & Reduce food waste & Hotel guests & 52 & Field & Observed & Defaults & Portion size & Yes \\
\hline Katz et al. (2016) & Water use & Reduce water use & Households & 934 & Field & Observed & Norms & Injunctive & Yes \\
\hline Katzev and Bachman (1982) & Transportation choices & Reduce driving & Households & 152 & Field & Reported & Financial & Monetary & No \\
\hline Katzev and Bachman (1982) & Transportation choices & Reduce driving & Households & 152 & Field & Reported & Financial & Monetary & No \\
\hline Katzev and Bachman (1982) & Transportation choices & Reduce driving & Households & 152 & Field & Reported & Defaults & Making it easy & No \\
\hline Katzev and Bachman (1982) & Transportation choices & Reduce driving & Households & 152 & Field & Reported & Financial & Non-monetary & No \\
\hline Katzev and Bachman (1982) & Transportation choices & Use public transportation & Households & 152 & Field & Observed & Financial & Monetary & No \\
\hline Katzev and Bachman (1982) & Transportation choices & Use public transportation & Households & 152 & Field & Observed & Financial & Monetary & Yes \\
\hline Katzev and Bachman (1982) & Transportation choices & Use public transportation & Households & 152 & Field & Observed & Defaults & Making it easy & No \\
\hline Katzev and Bachman (1982) & Transportation choices & Use public transportation & Households & 152 & Field & Observed & Financial & Non-monetary & Yes \\
\hline Kerr et al. (2012) & Land management & $\begin{array}{l}\text { Contribute resources to land } \\
\text { conservation } \\
\text { Contribute resources to land }\end{array}$ & Households & 560 & Field & Observed & Financial & Monetary & No \\
\hline Kerr et al. (2012) & Land management & conservation & Households & 560 & Field & Observed & Financial & Shared financial & No \\
\hline Kondylis et al. (2016) & Land management & Adopt conservation practices & Farmers & 5076 & Field & Reported & Messenger & Gender & Yes \\
\hline Kormos et al. (2014) & Transportation choices & Reduce driving & Drivers & 78 & Field & Reported & Norms & Descriptive & No \\
\hline Kormos et al. (2014) & Transportation choices & Reduce driving & Drivers & 78 & Field & Reported & Norms & Descriptive & No \\
\hline Kurz et al. (2005) & Water use & Reduce water use & Households & 166 & Field & Observed & Education & Data (general) & No \\
\hline Kurz et al. (2005) & Water use & Reduce water use & Households & 166 & Field & Observed & Norms & Descriptive & No \\
\hline Kurz et al. (2005) & Water use & Reduce water use & Households & 166 & Field & Observed & Salience & Reminder & Yes \\
\hline Liebig and Rommel (2014) & Waste production & Reduce paper waste & Households & 941 & Field & Observed & Defaults & Forced choice & Yes \\
\hline Lokhorst et al. (2010) & Land management & Adopt conservation practices & Farmers & 58 & Field & Reported & Education & Feedback (personal) & No \\
\hline Lokhorst et al. (2010) & Land management & Adopt conservation practices & Farmers & 58 & Field & Reported & Commitments & Public & No \\
\hline Lokhorst et al. (2010) & Land management & $\begin{array}{l}\text { Contribute resources to land } \\
\text { conservation } \\
\text { Contribute resources to land }\end{array}$ & Farmers & 58 & Field & Reported & Education & Feedback (personal) & No \\
\hline Lokhorst et al. (2010) & Land management & conservation & Farmers & 58 & Field & Reported & Commitments & $\begin{array}{l}\text { Public } \\
\text { Implementation }\end{array}$ & No \\
\hline Loy et al. (2016) & Meat consumption & Reduce meat consumption & Undergraduates & 55 & Field & Reported & Commitments & intentions & Yes \\
\hline Matthies et al. (2006) & Transportation choices & Use public transportation & Drivers & 297 & Field & Reported & Financial & Non-monetary & Yes \\
\hline Matthies et al. (2006) & Transportation choices & $\begin{array}{l}\text { Use public transportation } \\
\text { Contribute resources to land }\end{array}$ & Drivers & 297 & Field & Reported & Commitments & Plea for commitment & No \\
\hline Messer et al (2016) & Land management & $\begin{array}{l}\text { conservation } \\
\text { Contribute resources to land }\end{array}$ & Farmers & 371 & Field & Observed & Priming & Social desirability & No \\
\hline Messer et al. (2016) & Land management & $\begin{array}{l}\text { conservation } \\
\text { Contribute resources to land }\end{array}$ & Farmers & 371 & Field & Observed & Priming & Social desirability & Yes \\
\hline Messer et al. (2016) & Land management & conservation & Farmers & 371 & Field & Observed & Defaults & Status quo bias & Yes \\
\hline Middlestadt et al. (2001) & Water use & Reduce water use & High school students & 671 & Field & Reported & Education & How-to tips & Yes \\
\hline Monroe et al. (2015) & Meat consumption & Choose climate-friendly protein & Undergraduates & 491 & Field & Reported & Education & Training & Yes \\
\hline Richetin et al. (2016) & Water use & Reduce water use & Undergraduates & 41 & $\mathrm{Lab}$ & Observed & Norms & Descriptive & Yes \\
\hline Richetin et al. (2016) & Water use & Reduce water use & Undergraduates & 41 & $\mathrm{Lab}$ & Observed & Norms & Descriptive & Yes \\
\hline Richetin et al. (2016) & Water use & Reduce water use & Undergraduates & 40 & $\mathrm{Lab}$ & Observed & Norms & Descriptive & Yes \\
\hline Richetin et al. (2016) & Water use & Reduce water use & Undergraduates & 109 & $\mathrm{Lab}$ & Observed & Norms & $\begin{array}{l}\text { Descriptive } \\
\text { Environmental }\end{array}$ & Yes \\
\hline Rommel et al. (2015) & Waste production & Reduce paper waste & Households & 822 & Field & Observed & Education & impact & No \\
\hline Rommel et al. (2015) & Waste production & Reduce paper waste & Households & 822 & Field & Observed & Financial & Non-monetary & Yes \\
\hline
\end{tabular}




\begin{tabular}{|c|c|c|c|c|c|c|c|c|c|}
\hline Study & Domain & Behavior & Sampled population & $\begin{array}{l}\text { Sample } \\
\text { size }\end{array}$ & Setting & Measure & Target & $\begin{array}{l}\text { Intervention } \\
\text { specified }\end{array}$ & $\begin{array}{l}\text { Intervention } \\
\text { significant? }\end{array}$ \\
\hline Rommel et al (2015) & Waste production & Reduce paper waste & Households & 822 & Field & Observed & Norms & Social influence & No \\
\hline Rubens et al. (2015) & Waste production & Reduce plastic waste & Shoppers & 74 & Field & Observed & Commitments & Public & Yes \\
\hline Rubens et al. (2015) & Waste production & Reduce plastic waste & Shoppers & 74 & Field & Observed & Salience & Reminder & No \\
\hline Santos and van der Linden & Waste nroduction & Reduce plactic waste & Undergraduates & 1302 & Field & Penorted & Financial & Non monetary & Yes \\
\hline $\begin{array}{l}\text { (2016) } \\
\text { Schall and Mohnen (2015) }\end{array}$ & $\begin{array}{l}\text { Waste production } \\
\text { Transportation choices }\end{array}$ & $\begin{array}{l}\text { Reduce plastic waste } \\
\text { Improve driving efficiency }\end{array}$ & $\begin{array}{l}\text { Undergraduates } \\
\text { Drivers }\end{array}$ & $\begin{array}{l}1302 \\
86\end{array}$ & $\begin{array}{l}\text { Field } \\
\text { Field }\end{array}$ & $\begin{array}{l}\text { Reported } \\
\text { Observed }\end{array}$ & $\begin{array}{l}\text { Financial } \\
\text { Financial }\end{array}$ & $\begin{array}{l}\text { Non-monetary } \\
\text { Monetary }\end{array}$ & $\begin{array}{l}\text { Yes } \\
\text { No }\end{array}$ \\
\hline Schall and Mohnen (2015) & Transportation choices & Improve driving efficiency & Drivers & 86 & Field & Observed & Financial & Non-monetary & Yes \\
\hline Schmidt (2016) & Waste production & Reduce food waste & Households & 217 & Field & Reported & Commitments & Goal-setting & Yes \\
\hline Schultz et al. (2008) & Water use & Reuse hotel towels & Hotel guests & 2359 & Field & Observed & Norms & Aligned & Yes \\
\hline Schultz et al. (2008) & Water use & Reuse hotel towels & Hotel guests & 2359 & Field & Observed & Norms & Descriptive & No \\
\hline Schultz et al. (2008) & Water use & Reuse hotel towels & Hotel guests & 2359 & Field & Observed & Norms & Injunctive & No \\
\hline Schultz et al. (2008) & Water use & Reuse hotel towels & Hotel guests & 794 & Field & Observed & Norms & Aligned & Yes \\
\hline Schultz et al. (2008) & Water use & Reuse hotel towels & Hotel guests & 865 & Field & Observed & Norms & Descriptive & Yes \\
\hline Schultz et al. (2008) & Water use & Reuse hotel towels & Hotel guests & 865 & Field & Observed & Norms & Social influence & Yes \\
\hline Schultz et al. (2014) & Water use & Reduce water use & Households & 301 & Field & Observed & Norms & Aligned & Yes \\
\hline Schultz et al. (2014) & Water use & Reduce water use & Households & 301 & Field & Observed & Norms & Descriptive & Yes \\
\hline Schultz et al. (2014) & Water use & Reduce water use & Households & 301 & Field & Observed & Education & How-to tips & No \\
\hline Sebastian et al. (2012) & Family planning & Use contraception & Women and girls & 959 & Field & Reported & Education & How-to tips & Yes \\
\hline Seyranian et al. (2015) & Water use & Reduce water use & Households & 374 & Field & Observed & Norms & Aligned & Yes \\
\hline Seyranian et al. (2015) & Water use & Reduce water use & Households & 374 & Field & Observed & Education & How-to tips & No \\
\hline Seyranian et al. (2015) & Water use & Reduce water use & Households & 374 & Field & Observed & Salience & Identity & Yes \\
\hline Seyranian et al. (2015) & Water use & Reduce water use & Households & 374 & Field & Observed & Salience & $\begin{array}{l}\text { Identity } \\
\text { Implementation }\end{array}$ & Yes \\
\hline Taniguchi and Fujii (2007) & Transportation choices & Use public transportation & Households & 494 & Field & Reported & Commitments & intentions & Yes \\
\hline Terrier and Marfaing (2015a) & Water use & Reuse hotel towels & Hotel guests & 803 & Field & Observed & Norms & Descriptive & Yes \\
\hline Terrier and Marfaing (2015a) & Water use & Reuse hotel towels & Hotel guests & 803 & Field & Observed & Norms & Descriptive & Yes \\
\hline Terrier and Marfaing (2015a) & Water use & Reuse hotel towels & Hotel guests & 803 & Field & Observed & Commitments & $\begin{array}{l}\text { Implementation } \\
\text { intentions } \\
\text { Implementation }\end{array}$ & Yes \\
\hline Terrier and Marfaing (2015a) & Water use & Reuse hotel towels & Hotel guests & 803 & Field & Observed & Commitments & intentions & Yes \\
\hline$(2015 b)$ & Water use & Reuse hotel towels & Hotel guests & 187 & Field & Observed & Commitments & intentions & Yes \\
\hline Tertoolen et al. (1998) & Transportation choices & Use public transportation & Drivers & 350 & Field & Reported & Education & $\begin{array}{l}\text { Economic impact } \\
\text { Environmental }\end{array}$ & No \\
\hline Tertoolen et al. (1998) & Transportation choices & Use public transportation & Drivers & 350 & Field & Reported & Education & impact & No \\
\hline Thogerson (2009) & Transportation choices & Use public transportation & Drivers & 597 & Field & Reported & Financial & Non-monetary & Yes \\
\hline $\begin{array}{l}\text { Thompson and Stoutemyer } \\
\text { (1991) } \\
\text { Thompson and Stoutemver }\end{array}$ & Water use & Reduce water use & Households & 171 & Field & Observed & Education & $\begin{array}{l}\text { Economic impact } \\
\text { Environmental }\end{array}$ & No \\
\hline (1991) & Water use & Reduce water use & Households & 171 & Field & Observed & Education & impact & Yes \\
\hline $\begin{array}{l}\text { Thompson and Stoutemyer } \\
\text { (1991) }\end{array}$ & Water use & Reduce water use & Households & 171 & Field & Observed & Education & How-to tips & Yes \\
\hline (2014) & Transportation choices & Improve driving efficiency & Drivers & 700 & Field & Observed & Education & Data (general) & No \\
\hline $\begin{array}{l}\text { Yeomans and Herberich } \\
\text { (2014) }\end{array}$ & Transportation choices & Improve driving efficiency & Drivers & 700 & Field & Observed & Norms & Descriptive & No \\
\hline $\begin{array}{l}\text { Yeomans and Herberich } \\
\text { (2014) }\end{array}$ & Transportation choices & Improve driving efficiency & Drivers & 700 & Field & Observed & Financial & Monetary & Yes \\
\hline $\begin{array}{l}\text { Yeomans and Herberich } \\
\text { (2014) }\end{array}$ & Transportation choices & Improve driving efficiency & Drivers & 700 & Field & Observed & Financial & Non-monetary & Yes \\
\hline
\end{tabular}




\section{WebReferences}

Ahmed S, Ahmed S, McKaig C, et al. 2015. The effect of integrating family planning with a maternal and newborn health program on postpartum contraceptive use and optimal birth spacing in rural Bangladesh. Studies in Family Planning 46: 297-312.

Andrews AC, Clawson RA, Gramig BM, and Raymond L. 2013. Why do farmers adopt conservation tillage? An experimental investigation of framing effects. Journal of Soil and Water Conservation 68: 501-11.

Ashraf N, Field E, and Lee J. 2014. Household bargaining and excess fertility: an experimental study in Zambia. American Economic Review 104: 2210-37.

Baca-Motes K, Brown A, Gneezy A, et al. 2013. Commitment and behavior change: evidence from the field. Journal of Consumer Research 39: 1070-84.

Bachman W and Katzev R. 1982. The effects of non-contingent free bus tickets and personal commitment on urban bus ridership. Transportation Research Part A: General 16: 103-8.

Bamberg S. 2002. Effects of implementation intentions on the actual performance of new environmentally friendly behaviours - Results of two field experiments. Journal of Environmental Psychology 22: 399411.

Bamberg S. 2006. Is a residential relocation a good opportunity to change people's travel behavior? Results from a theory-driven intervention study. Environment and Behavior 38: 820-40.

Bandiera O, Buehren N, Burgess R, et al. 2012. Empowering adolescent girls: Evidence from a randomized control trial in Uganda. Washington, DC: World Bank.

Bandiera O, Burgess R, Goldstein M, et al. 2015. Women's empowerment in action: evidence from a randomized control trial in Africa. London, UK: The London School of Economics and Political Science, Suntory and Toyota International Centres for Economics and Related Disciplines.

Bashour HN, Kharouf MH, AbdulSalam AA, et al. 2008. Effect of postnatal home visits on maternal/infant outcomes in Syria: a randomized controlled trial. Public Health Nursing 25: 115-25.

Beale JR and Bonsall PW. 2007. Marketing in the bus industry: a psychological interpretation of some attitudinal and behavioural outcomes. Transportation Research Part F: Traffic Psychology and Behaviour 10: 271-287.

Bolderdijk JW, Steg L, Geller ES, et al. 2013. Comparing the effectiveness of monetary versus moral motives in environmental campaigning. Nature Clim Change 3: 413-6.

Brent DA, Cook JH, and Olsen S. 2015. Social comparisons, household water use, and participation in utility conservation programs: evidence from three randomized trials. Journal of the Association of Environmental and Resource Economists 2: 597-627.

Campbell-Arvai V and Arvai J. 2015. The promise of asymmetric interventions for addressing risks to environmental systems. Environ Syst Decis 35: 472-82.

Campbell-Arvai V, Arvai J, and Kalof L. 2014. Motivating sustainable food choices: the role of nudges, value orientation, and information provision. Environment and Behavior 46: 453-75.

Chong A, Gonzalez-Navarro M, Karlan D, and Valdivia M. 2013. Effectiveness and spillovers of online sex education: Evidence from a randomized evaluation in Colombian public schools. National Bureau of Economic Research.

Cobern MK, Porter BE, Leeming FC, and Dwyer WO. 1995. The effect of commitment on adoption and diffusion of grass cycling. Environment and Behavior 27: 213-32.

Datta S, Miranda JJ, Zoratto LDC, et al. 2015. A behavioral approach to water conservation: evidence from Costa Rica. The World Bank.

Desai J and Tarozzi A. 2011. Microcredit, family planning programs, and contraceptive behavior: evidence from a field experiment in Ethiopia. Demography 48: 749-82.

Dickerson CA, Thibodeau R, Aronson E, and Miller D. 1992. Using cognitive dissonance to encourage water conservation. Journal of Applied Social Psychology 22: 841-54.

Egebark J and Ekström M. 2016. Can indifference make the world greener? Journal of Environmental Economics and Management 76: 1-13. 
Eriksson L, Garvill J, and Nordlund AM. 2008. Interrupting habitual car use: the importance of car habit strength and moral motivation for personal car use reduction. Transportation Research Part F: Traffic Psychology and Behaviour 11: 10-23.

Ferraro PJ and Price MK. 2013. Using nonpecuniary strategies to influence behavior: evidence from a largescale field experiment. Review of Economics and Statistics 95: 64-73.

Fielding KS, Spinks A, Russell S, et al. 2013. An experimental test of voluntary strategies to promote urban water demand management. Journal of Environmental Management 114: 343-51.

Geller ES, Erickson JB, and Buttram BA. 1983. Attempts to promote residential water conservation with educational, behavioral and engineering strategies. Popul Environ 6: 96-112.

Goldstein NJ, Cialdini RB, and Griskevicius V. 2008. A room with a viewpoint: using social norms to motivate environmental conservation in hotels. Journal of Consumer Research 35: 472-82.

Goldstein NJ, Griskevicius V, and Cialdini RB. 2011. Reciprocity by proxy: a novel influence strategy for stimulating cooperation. Administrative Science Quarterly 56: 441-73.

Groot JIM de, Abrahamse W, and Jones K. 2013. Persuasive normative messages: the influence of injunctive and personal norms on using free plastic bags. Sustainability 5: 1829-44.

Hamann KRS, Reese G, Seewald D, and Loeschinger DC. 2015. Affixing the theory of normative conduct (to your mailbox): Injunctive and descriptive norms as predictors of anti-ads sticker use. Journal of Environmental Psychology 44: 1-9.

Hou MY, Hurwitz S, Kavanagh E, et al. 2010. Using daily text-message reminders to improve adherence with oral contraceptives: a randomized controlled trial. Obstetrics \& Gynecology 116: 633-40.

Jakobsson C, Fujii S, and Gärling T. 2002. Effects of economic disincentives on private car use. Transportation 29: 349-70.

Jayachandran S, De Laat J, Lambin EF, and Stanton CY. 2016. Cash for Carbon: A Randomized Controlled Trial of Payments for Ecosystem Services to Reduce Deforestation. National Bureau of Economic Research.

Kallbekken S and Sælen H. 2013. 'Nudging' hotel guests to reduce food waste as a win-win environmental measure. Economics Letters 119: 325-7.

Katz D, Grinstein A, Kronrod A, and Nisan U. 2016. Evaluating the effectiveness of a water conservation campaign: Combining experimental and field methods. Journal of Environmental Management 180: 335-43.

Katzev R and Bachman W. 1982. Effects of deferred payment and fare manipulations on urban bus ridership. Journal of Applied Psychology 67: 83-8.

Kerr J, Vardhan M, and Jindal R. 2012. Prosocial behavior and incentives: evidence from field experiments in rural Mexico and Tanzania. Ecological Economics 73: 220-7.

Kondylis F, Mueller V, Sheriff G, and Zhu S. 2016. Do female instructors reduce gender bias in diffusion of sustainable land management techniques? Experimental evidence from Mozambique. World Development 78: 436-49.

Kormos C, Gifford R, and Brown E. 2015. The influence of descriptive social norm information on sustainable transportation behavior. Environment and Behavior 47: 479-501.

Kurz T, Donaghue N, and Walker I. 2005. Utilizing a social-ecological framework to promote water and energy conservation: a field experiment. Journal of Applied Social Psychology 35: 1281-300.

Liebig G and Rommel J. 2014. Active and forced choice for overcoming status quo bias: a field experiment on the adoption of "no junk mail" stickers in Berlin, Germany. Journal of Consumer Policy 37: 423-35.

Lokhorst AM, Dijk J van, Staats H, et al. 2009. Using tailored information and public commitment to improve the environmental quality of farm lands: an example from the Netherlands. Human Ecology 38: 113-22.

Loy LS, Wieber F, Gollwitzer PM, and Oettingen G. 2016. Supporting sustainable food consumption: mental contrasting with implementation intentions (MCII) aligns intentions and behavior. Frontiers in Psychology 7: 607.

Matthies E, Klöckner CA, and Preißner CL. 2006. Applying a modified moral decision making model to change habitual car use: how can commitment be effective? Applied Psychology 55: 91-106.

Messer KD, Ferraro PJ, and Allen W. 2016. Behavioral nudges in competitive environments: a field experiment examining defaults and social comparisons in a conservation contract auction. University of Delaware. 
Middlestadt S, Grieser M, Hernández O, et al. 2001. Turning minds on and faucets off: water conservation education in Jordanian schools. The Journal of Environmental Education 32: 37-45.

Monroe JT, Lofgren IE, Sartini BL, and Greene GW. 2015. The Green Eating Project: web-based intervention to promote environmentally conscious eating behaviours in US university students. Public Health Nutrition 18: 2368-78.

Richetin J, Perugini M, Mondini D, and Hurling R. 2016. Conserving water while washing hands: the immediate and durable impacts of descriptive norms. Environment and Behavior 48: 343-64.

Rommel J, Buttmann V, Liebig G, et al. 2015. Motivation crowding theory and pro-environmental behavior: experimental evidence. Economics Letters 129: 42-4.

Rubens L, Gosling P, Bonaiuto M, et al. 2015. Being a hypocrite or committed while i am shopping? A comparison of the impact of two interventions on environmentally friendly behavior. Environment and Behavior 47: 3-16.

Santos JM and Linden S van der. 2016. Changing norms by changing behavior: the Princeton drink local program. Environmental Practice 18: 116-22.

Schall DL and Mohnen A. 2015. Incentivizing energy-efficient behavior at work: an empirical investigation using a natural field experiment on eco-driving. Applied Energy.

Schmidt K. 2016. Explaining and promoting household food waste-prevention by an environmental psychological based intervention study. Resources, Conservation and Recycling 111: 53-66.

Schultz PW, Khazian AM, and Zaleski AC. 2008. Using normative social influence to promote conservation among hotel guests. Social Influence 3: 4-23.

Schultz PW, Messina A, Tronu G, et al. 2014. Personalized normative feedback and the moderating role of personal norms: a field experiment to reduce residential water consumption. Environment and Behavior 48: 686-710.

Sebastian MP, Khan ME, Kumari K, and Idnani R. 2012. Increasing postpartum contraception in rural India: evaluation of a community-based behavior change communication intervention. International Perspectives on Sexual and Reproductive Health 38: 68-77.

Seyranian V, Sinatra GM, and Polikoff MS. 2015. Comparing communication strategies for reducing residential water consumption. Journal of Environmental Psychology 41: 81-90.

Taniguchi A and Fujii S. 2007. Promoting public transport using marketing techniques in mobility management and verifying their quantitative effects. Transportation 34: 37-49.

Terrier L and Marfaing B. 2015a. Using binding communication to promote conservation among hotel guests. Swiss Journal of Psychology 74: 169-75.

Terrier L and Marfaing B. 2015b. Using social norms and commitment to promote pro-environmental behavior among hotel guests. Journal of Environmental Psychology 44: 10-5.

Tertoolen G, Van Kreveld D, and Verstraten B. 1998. Psychological resistance against attempts to reduce private car use. Transportation Research Part A: Policy and Practice 32: 171-181.

Thøgersen J. 2009. Promoting public transport as a subscription service: effects of a free month travel card. Transport Policy 16: 335-43.

Thompson SC and Stoutemyer K. 1991. Water use as a commons dilemma: the effects of education that focuses on long-term consequences and individual action. Environment and Behavior 23: 314-33.

Yeomans M and Herberich D. 2014. An experimental test of the effect of negative social norms on energyefficient investments. Journal of Economic Behavior \& Organization 108: 187-97.

Young R de, Duncan A, Frank J, et al. 1993. Promoting source reduction behavior the role of motivational information. Environment and Behavior 25: 70-85. 


\section{Nudging pro-environmental behavior: evidence and opportunities}

Hilary Byerly ${ }^{1,2 *}$, Andrew Balmford ${ }^{3}$, Paul J Ferraro ${ }^{4}$, Courtney Hammond Wagner ${ }^{1,2}$, Elizabeth Palchak ${ }^{1,2}$, Stephen Polasky ${ }^{5}$, Taylor H Ricketts ${ }^{1,2}$, Aaron J Schwartz ${ }^{1,2}$, and Brendan Fisher ${ }^{1,2}$

Human behavior is responsible for many of our greatest environmental challenges. The accumulated effects of many individual and household decisions have major negative impacts on biodiversity and ecosystem health. Human behavioral science blends psychology and economics to understand how people respond to the context in which they make decisions (eg who presents the information and how it is framed). Behavioral insights have informed new strategies to improve personal health and financial choices. However, less is known about whether and how these insights can encourage choices that are better for the environment. We review 160 experimental interventions that attempt to alter behavior in six domains in which decisions have major environmental impacts: family planning, land management, meat consumption, transportation choices, waste production, and water use. The evidence suggests that social influence and simple adjustments to decision settings can influence pro-environmental decisions. We identify four important gaps in the evidence that provide opportunities for future research. To address these gaps, we encourage collaborations between researchers and practitioners that look at the effects of embedding tests of behavior-change interventions within environmental programs.

Front Ecol Environ 2018; 16(3): 159-168, doi: 10.1002/fee.1777

【uman behavior is a key determinant of the state of 1 the environment. Individual consumption and lifestyle choices contribute greatly to climate change (IPCC 2014), ecosystem conversion and biodiversity loss (Foley et al. 2005), and water scarcity (Wada and Bierkens 2014). These impacts are projected to worsen as the size and wealth of the global human population continue to grow (Ferrara and Serrat 2008); as such, modifying human behavior is essential for addressing environmental challenges (Fischer et al. 2012; Cowling 2014).

\section{In a nutshell:}

- Insights into human behavior offer new options for influencing people's choices in ways that will affect the environment

- Experimental evidence suggests that information about social norms and changes to the decision context can encourage pro-environmental behavior, especially in relation to water conservation, sustainable land management, and reduced meat consumption

- Large gaps in our understanding of how particular interventions can influence people's choices will require further research using well-designed experiments that measure cost-effectiveness and behavior-change over time

${ }^{1}$ Gund Institute for Environment, University of Vermont, Burlington, VT; ${ }^{2}$ Rubenstein School of Environment and Natural Resources, University of Vermont, Burlington, VT *(hbyerly@uvm.edu); ${ }^{3}$ Conservation Science Group, Department of Zoology, University of Cambridge, Cambridge, UK; ${ }^{4}$ Carey Business School and Department of Environmental Health and Engineering, Bloomberg School of Public Health and Whiting School of Engineering, Johns Hopkins University, Baltimore, MD; ${ }^{5}$ Department of Applied Economics, University of Minnesota, St Paul, MN
Non-regulatory policies and programs designed to influence decision making have historically been shaped by the economic model of the "rational actor". With limitless cognitive capacity for evaluating decisions and attention only to private costs and benefits, this actor responds to information and incentives. However, there is ample evidence that people are sensitive to the behavior of others and are not strictly self-interested (Ostrom 2000; Nyborg et al. 2016). Insights from psychology, economics, and neuroscience further suggest that cognitive constraints and biases play important roles in how people make decisions (Simon 1955; Tversky and Kahneman 1974).

In fact, people respond not only to incentives, information, and persuasion, but also to how these interventions are framed and communicated (Kahneman et al. 1991; Kamenica 2012). Altering the context within which decisions are made can encourage socially desirable behaviors and discourage socially undesirable ones (Figure 1). For example, people are generally motivated to keep their promises and attain their goals, so asking for commitments (whether written or oral, public or private) may increase the likelihood of certain actions. Other behaviors are more likely to follow the status quo, or the default setting, in a given situation. Choices can be swayed by the identity of the person, or messenger, who suggests the behavior change, and communicating social norms, such as expectations or peer comparisons, can influence how individuals behave. People also respond to information that is made accessible in their mind (via priming) and to which their attention is repeatedly drawn (via salience) (Figure 2). Unlike financial incentives and education, which target controlled, conscious delibera- 

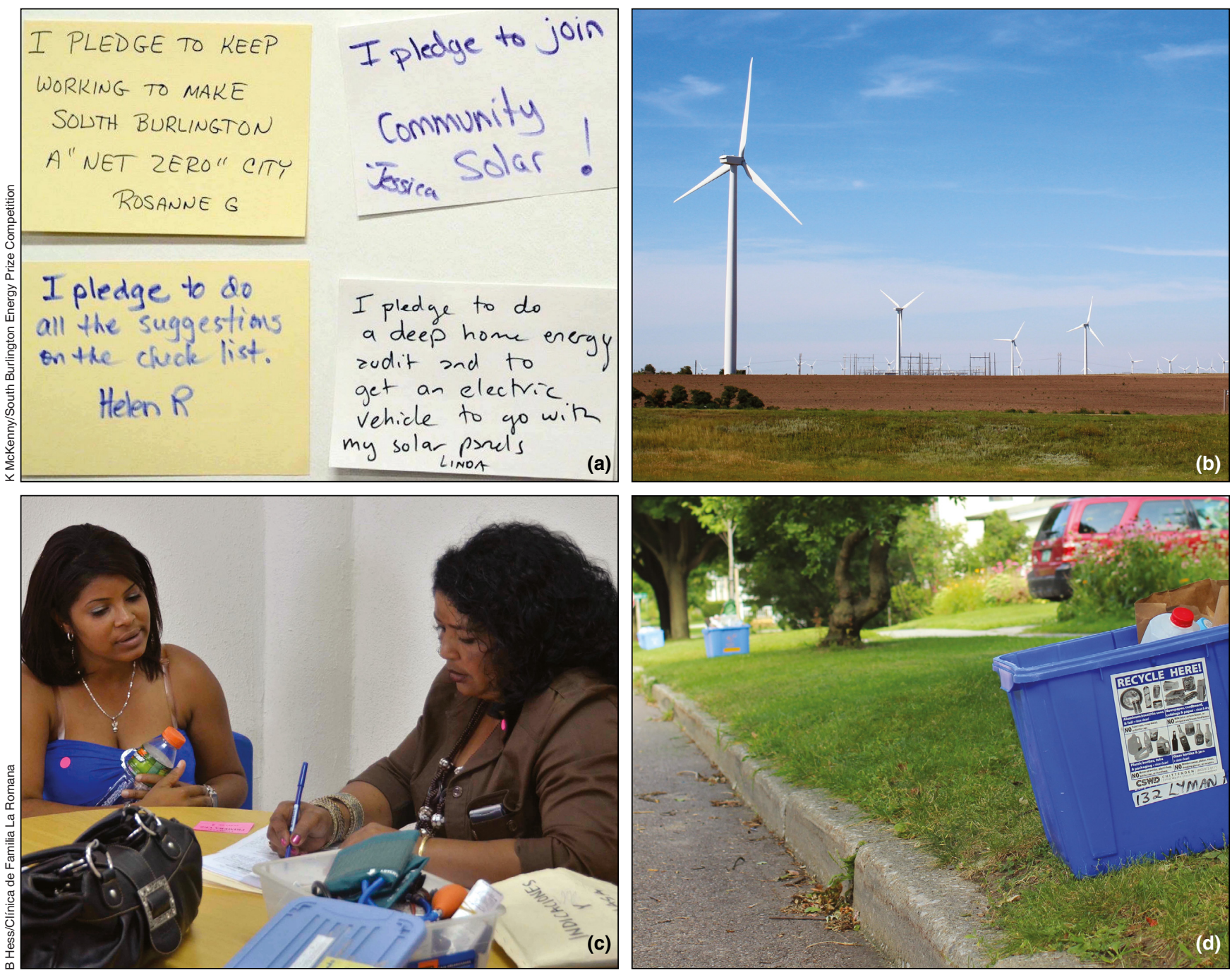

Figure 1. Examples of targeting contextual variables to increase pro-social and pro-environmental behavior. (a) Pledges elicit commitments that spur action to reduce energy use; (b) automatically enrolling consumers in green energy programs increases participation compared to a default where people must opt in; (c) health information is more effective when the messenger suggesting the behavior change is perceived as similar; $(d)$ the behavior of peers and neighbors indicates social norms that promote recycling.

tion, these contextual variables often moderate behavior through automatic, unconscious cognitive processes (Dolan et al. 2012).

Applications of these insights from behavioral science have been shown to have positive effects on both individual and social welfare. Changing the context in which choices are presented can encourage people to save for retirement (Thaler and Benartzi 2004), make healthier diet and lifestyle choices (Downs et al. 2009; Volpp et al. 2011), and participate in socially beneficial programs such as organ donation (Johnson and Goldstein 2003). Yet the potential for behavioral insights to advance sustainability is unrealized in many environmental policies and programs (Clayton et al. 2013; Dietz 2014; Reddy et al. 2017).

There is evidence that interventions targeting these contextual variables can improve recycling rates and reduce energy use (see Panel 1 for an overview), but whether such approaches can influence other environ- mentally relevant behaviors is not as well understood. We review the experimental evidence on behaviorchange interventions in six other domains in which individual decisions have large environmental impacts (hereafter, "domains"): family planning, land management, meat consumption, transportation choices, waste production, and water use. For each of these six domains, we evaluate the effectiveness of eight sets of contextual interventions (hereafter, "interventions"; Figure 3). Six of these sets of interventions aim to affect the contextual variables - commitments, defaults, messenger, norms, priming, and salience - described above. We contrast these contextual interventions with two sets of traditional behavior-change interventions - financial incentives and education - that target the cost-benefit calculations of the rational actor. These traditional interventions set the performance benchmark against which contextual interventions can be compared - a comparison that allows us to draw conclusions on the full suite of behavior-change 

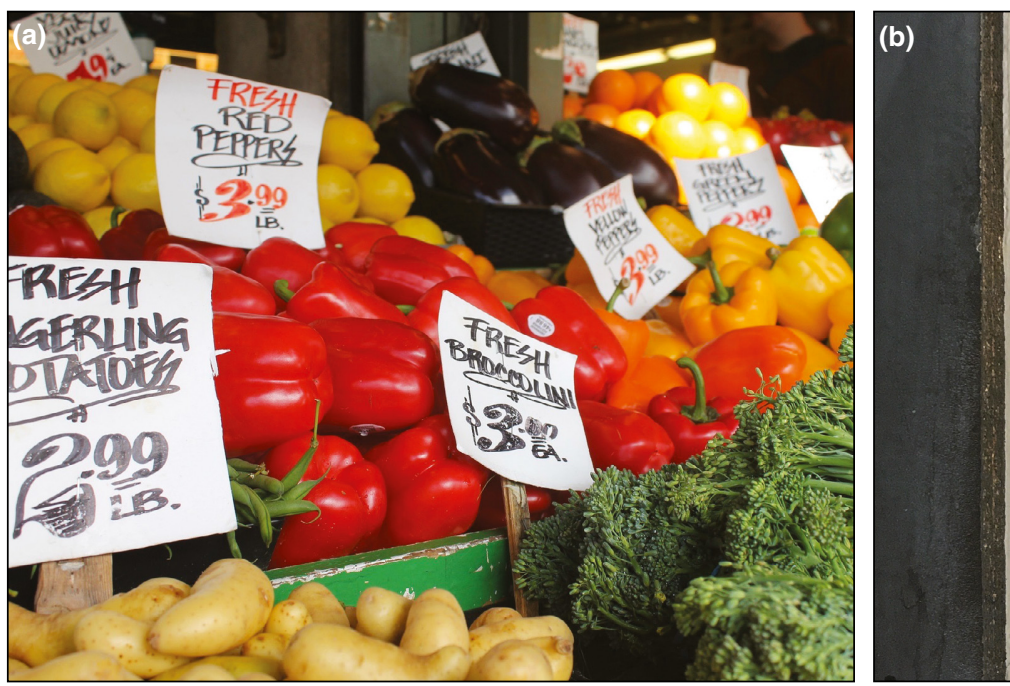

Figure 2. Examples of using priming and salience to influence behavior. (a) Displays of healthy foods prime shoppers to purchase healthier food items; (b) reminders and prompts make energy use and conservation salient.

options available to policy makers and those designing conservation programs.

We seek to address three questions: (1) What is already known about using contextual interventions to change environmentally important behaviors? (2) Are there interventions that have proven effective across domains? (3) How should we prioritize further research on behavioral science to address environmental challenges?

\section{Methods}

We conducted a systematic literature review to examine the effects of contextual interventions on proenvironmental behavior in the six environmentally relevant domains described above (Figure 3). We confined our review to studies that employed experimental designs in order to draw conclusions about the causal impact of interventions on behavior. Our review was guided by four criteria: (1) experiments that (2) focused on pro-environmental behavior changes (3) in contexts related to our six domains and (4) reported statistical inferences. "Experiments" refer to empirical designs in which exposure to a condition/treatment was experimentally manipulated across or within subjects to permit unbiased causal inference. "Behavior changes" refer to self-reported or observed behaviors rather than knowledge, attitudes, or intentions. The behaviors of interest in each domain were those that have the potential

Panel 1. Behavioral evidence in recycling and energy use

\section{Recycling}

The experimental literature on recycling dates back to the 1980s. Today, waste management behaviors - recycling and not littering, in particular - have become so embedded in some countries that many consider them normative (Gould et al. 2016).

Changing defaults, such as adding bins for recycled goods alongside trashcans and offering curbside pickup on the same day as trash pickup, has been shown to encourage recycling. Messenger interventions (via neighbors) and commitments (via goal setting, verbal promises, and public statements) have also increased recycling. Social norms, in the form of comparative feedback and visual presence of curbside pickup, promoted recycling behavior, but the effect was often mediated by personal values. Recent reviews have demonstrated that large gaps remain in our understanding of the specific moderators and mechanisms that influence recycling behavior-change, particularly over the long term.

See reviews by Schultz et al. (1995); Osbaldiston and Schott (20I2); Abrahamse and Steg (20I3); Kirakozian (20I6); and Maki et al. (20|6).

\section{Energy}

Research on behavioral interventions for energy use began in the 1970s, and has focused largely on reducing residential energy consumption and improving energy efficiency. Multiple metaanalyses and review articles synthesize the experimental evidence on energy behavior research.

Salience (frequent, in-home reminders of current use) and commitments (goals for reducing use) have made energy-use feedback more effective in changing individual behavior toward energy conservation. Defaults that automatically enroll customers in efficiency or green energy programs have also increased participation compared to optin programs. Comparison messages about neighbors' energy use have been widely employed to target social norms and have resulted in a range of treatment effects, although they can be less impactful than other contextual interventions in reducing energy use. Messenger effects warrant further research; for instance, engaging "block leaders" in neighborhoods and model employees in offices have been shown to influence energy behavior, but the results and contexts are limited.

See reviews by Abrahamse et al. (2005); Osbaldiston and Schott (20I2); Abrahamse and Steg (20I3); Delmas et al. (20I3); and Karlin et al. (20I5). 


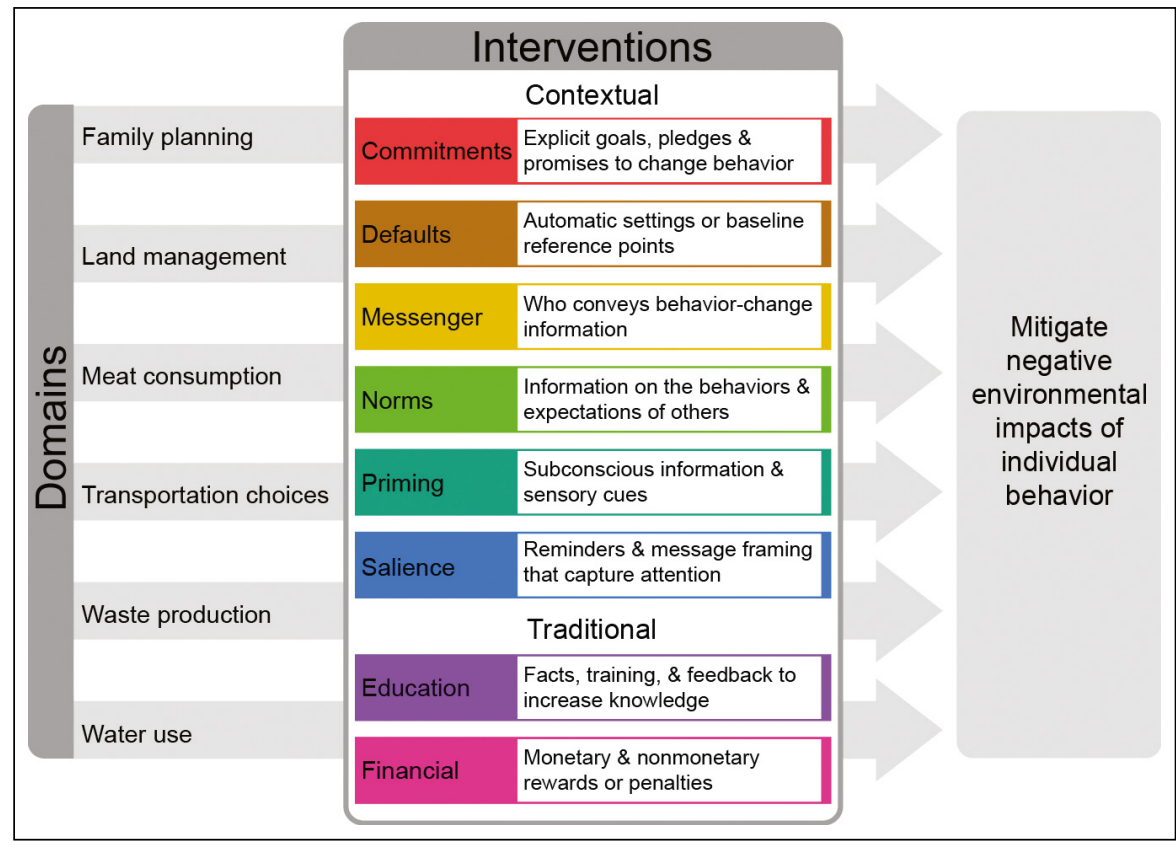

Figure 3. Behavior-change interventions that target decision making in six domains where human behavior has large impacts on the environment. See Panel 1 for a summary of evidence on energy use and recycling. Variables are adapted from Dolan et al. (2012). not report study effect sizes or weight the studies by quality. The behavioral outcomes across domains vary greatly and a large number of studies did not report all the elements necessary to calculate standardized effect sizes. Moreover, some studies used self-reported outcomes or experienced treatment noncompliance, which can affect their internal validity. Second, because we count multiple outcome estimates from a single study separately, our review is prone to the "multiple comparison problem" (inflated Type I errors). Third, despite inclusion of six unpublished papers, selective publication of studies may have biased conclusions toward statistically significant effects. Also, researchers themselves are possibly biased in their selection of interventions to test. Finally, not all tested interventions fit perfectly into our defined categories. Despite

to mitigate negative environmental impacts, such as using contraception (as a means of reducing population growth), regardless of whether the intent of the experimenter was environmentally motivated. We identified search terms within each of these domains (WebTable 1) and used them in combination with the words experiment, intervention, treatment, control, behavior, sustainable, and pro-environmental, and with the eight behavior-change interventions commitment, default, messenger, norms, priming, salience, financial incentives, and education. Searches were conducted in Web of Science, PsycINFO, EconLit, other electronic databases, relevant journals, and the citations listed in included papers. Our search centered on peer-reviewed literature but working papers from active researchers in the field were also included.

The studies that met our criteria were coded according to domain, behavior, sampled population, sample size, setting (field or lab), measure (reported or observed), intervention target, intervention tested, and statistical significance of each treatment. Our unit of analysis was a single intervention within a study; by intervention, we are referring to a treatment and its measured impact on a unique behavioral outcome. For experiments that measured multiple behavioral outcomes (eg used contraception and reduced sexual activity), each behavior counted separately. Two authors independently coded each study ( $81 \%$ agreement) and discrepancies were reconciled through discussion. The full set of reviewed studies is listed in WebTable 2.

Our objective was to give the reader a broad survey of multiple domains and interventions, and to achieve this we constrained our review in several ways. First, we do these limitations, we believe our analysis offers a useful perspective on the state of the evidence.

\section{Evidence for pro-environmental behavior change}

We identified 72 studies that tested a total of 160 interventions across our six domains (Table 1). Nearly all studies (96\%) were conducted in the field, as opposed to a laboratory, and almost three-quarters (73\%) measured observed, rather than self-reported, behaviors. Sample sizes ranged from 23 to over 100,000 participants, with a median of 379 . The majority of estimates addressed water use and transportation choices, whereas the fewest targeted land management and meat consumption (Figure 4). Norms were the most frequently affected contextual variable (48 times), followed by commitments (25), salience (11), defaults (8), priming (2), and messenger (1). The two traditional approaches of financial incentives and education were targeted 29 and 36 times, respectively.

\section{Family planning}

The behavioral outcomes in this domain were measured by contraception use, fertility rate (actual births), and sexual activity (Table 1). Although tested only once, an intervention targeting norms showed a strong effect on family planning. Women offered contraception vouchers when alone were $25 \%$ more likely to use contraception and $27 \%$ less likely to give birth than women who received the voucher in the presence of their husbands (Ashraf et al. 2014). A single study of 
Table 1. Summary of included studies

\begin{tabular}{|c|c|c|c|c|c|}
\hline Domain & Behavior & Interventions & Observed & Studies & Sample size \\
\hline \multirow[t]{3}{*}{ Family planning } & Reduce fertility rate & 4 & $75 \%$ & 9 & $73-6275$ \\
\hline & Reduce sexual activity & 2 & $0 \%$ & & \\
\hline & Use contraception & 10 & $30 \%$ & & \\
\hline \multirow[t]{2}{*}{ Land management } & Adopt conservation practices & 5 & $40 \%$ & 7 & $58-5076$ \\
\hline & Contribute resources to conservation & 9 & $78 \%$ & & \\
\hline \multirow[t]{3}{*}{ Meat consumption } & Choose climate-friendly protein & I & $0 \%$ & 4 & $55-491$ \\
\hline & Eat vegetarian foods & 4 & $100 \%$ & & \\
\hline & Reduce meat consumption & I & $0 \%$ & & \\
\hline \multirow[t]{3}{*}{ Transportation choices } & Improve driving efficiency & 7 & $100 \%$ & 16 & $23-700$ \\
\hline & Reduce driving & 11 & $0 \%$ & & \\
\hline & Use public transport & 21 & $52 \%$ & & \\
\hline \multirow[t]{3}{*}{ Waste production } & Reduce food waste & 3 & $67 \%$ & 10 & $52-1302$ \\
\hline & Reduce paper waste & 9 & $100 \%$ & & \\
\hline & Reduce plastic waste & 9 & $56 \%$ & & \\
\hline \multirow[t]{4}{*}{ Water use } & Participate in conservation programs & 3 & $100 \%$ & 26 & $40-106,669$ \\
\hline & Reduce water use & 40 & $98 \%$ & & \\
\hline & Reuse hotel towels & 21 & $100 \%$ & & \\
\hline & Total & 160 & $73 \%$ & 72 & \\
\hline
\end{tabular}

Notes: Behavior is the outcome variable used to measure the effect of an Intervention (see Figure 3); a single Study may test multiple interventions; Observed shows the proportion of interventions that are evaluated on an observed (versus self-reported) behavior change; and Sample size shows the lower and upper bounds of the sample sizes for studies in that domain.

the effect of salience, via daily reminders to use contraception, failed to detect an effect on the rate of missed birth control pills compared to a control group that received no reminder (Hou et al. 2010).

More than two-thirds of tested interventions in our search were educational, with overall mixed results (similar to the results of a systematic review performed by Mwaikambo et al. [2011]). Financial incentives were tested in only one study, in which neither access to microcredit nor microcredit combined with family planning services affected contraception use compared to a control group that received neither (Desai and Tarozzi 2011).

\section{Land management}

Outcome measures in this domain were divided between adopting sustainable land management practices and committing resources toward conservation. In one example of a messenger intervention, adoption of sustainable agriculture increased when the gender of the farmer was the same as the gender of the agricultural extension agent (Kondylis et al. 2016). Switching the default costshare from $0 \%$ to $100 \%$ in an auction to engage farmers in conservation actions increased the amount farmers were willing to pay by $9 \%$ (Messer et al. 2016). In the same study, priming farmers to perceive a conservation practice as socially desirable (ie by indicating that their peers approved of the practice) increased the likelihood of bidding but had no effect on the amount farmers were willing to pay. Commitments to dedicate land or time toward conservation had mixed results, and no effect was detected for a test of salience, which framed information about conservation tillage as either profitable or environmentally beneficial (Andrews et al. 2013).

Traditional interventions produced mixed findings. Paying forest-owning Ugandan households not to cut trees reduced the rate of deforestation by one-half as compared to forests owned by households that did not receive such financial incentives (Jayachandran et al. 2016), but no effect was detected where payments were made in exchange for communal litter collection (Kerr et al. 2012), nor did information about conservation practices have an effect on farmers' time spent on those practices (Lokhorst et al. 2010).

\section{Meat consumption}

Studies on meat consumption measured vegetarian meal purchases and self-reported changes in eating meat. Changing the default cafeteria menu to vegetarian-only and moving meat-based options to a separate menu increased the proportion of vegetarian meals ordered by 50\% (Campbell-Arvai et al. 2014) and increased the odds of choosing vegetarian meals by a factor of 15 (Campbell-Arvai and Arvai 2015). Commitments to eat less meat reduced meat consumption by $15 \%$ compared 


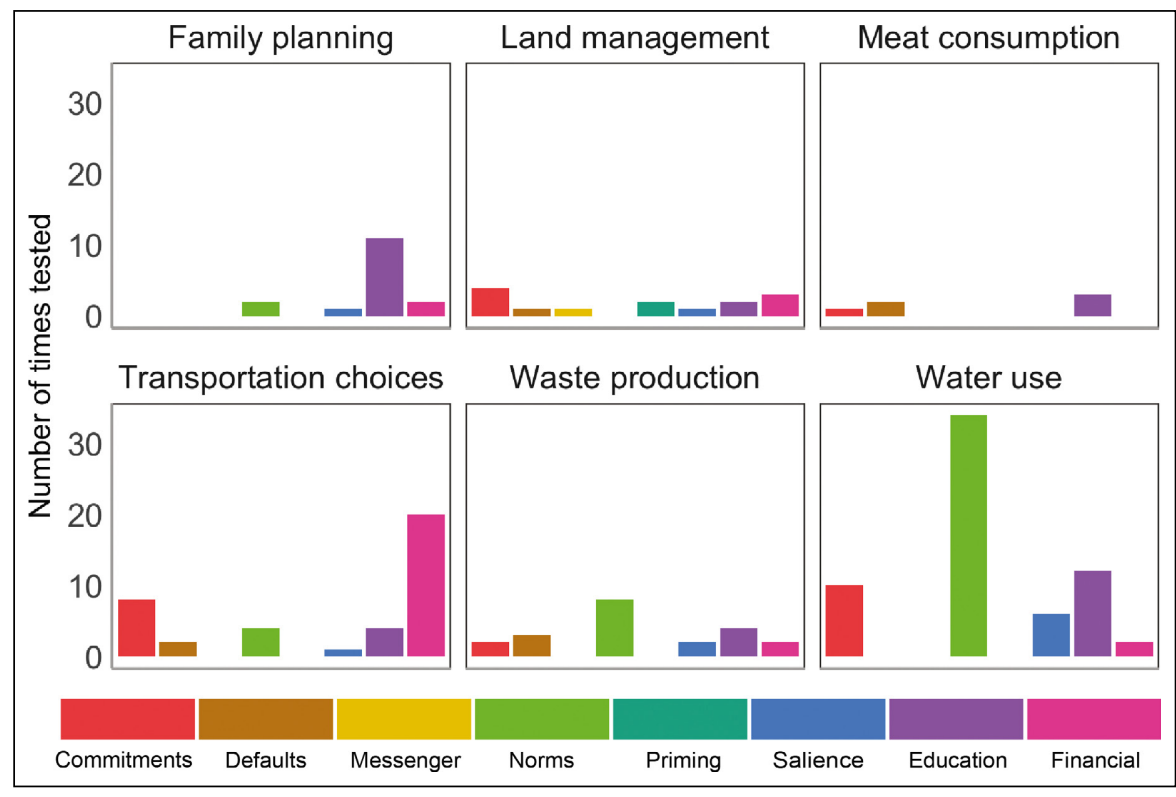

Figure 4. Number of tested behavior-change interventions across six domains of environmentally impactful behavior. Column order is expressed in the key at the bottom of the chart. An empty column indicates we found no tested interventions targeting that contextual variable in that domain.

to a group that only received information about the impacts of meat consumption (Loy et al. 2016).

Of the three experiments that tested education interventions, one study found that education resulted in a self-reported reduction of meat consumption, although the estimated effect was small (Monroe et al. 2015), and two studies could not detect differences in the levels of meat consumption between groups that received education and those that did not (Campbell-Arvai et al. 2014; Campbell-Arvai and Arvai 2015).

\section{Transportation choices}

Studies in this domain focused on three types of transportation behavior: driving efficiency, self-reported driving behavior, and public transportation use. Only one contextual intervention, which targeted salience, showed an effect on transportation behavior. Targeting salience by highlighting the environmental, rather than the economic, impacts of driving increased the likelihood of improving driving efficiency, although the sample size was small ( $n=23$; Bolderdijk et al. 2013). Evidence on commitments was split: three studies found that personal goals to use public transportation were effective, whereas three other studies failed to detect effects. No effect was found when social norms were targeted, nor did facilitating the purchase of tickets by bus riders (by changing the default payment method) have an effect (Katzev and Bachman 1982).

Most of the experimental literature within this domain focused on financial interventions (Figure 4). Direct financial incentives, such as monetary payments, charges, and discounts, largely had no effect. However, other non-monetary incentives, including free bus tickets, travel vouchers, and prizes, encouraged sustainable transportation behavior.

\section{Waste production}

This domain focused on behavioral outcomes related to waste production (ie reducing consumption) rather than waste disposal (but see the section on recycling in Panel 1). Results here offer evidence in favor of defaults and commitments in lowering the amount of food, paper, and plastic waste. Making the default plate size smaller reduced food waste by $20 \%$ (Kallbekken and Sælen 2013) and switching default printer settings to double-sided printing reduced paper consumption at a university by $15 \%$ per day (Egebark and Ekström 2016). Commitments increased selfreported food waste prevention behaviors in households and made shoppers $29 \%$ more likely to refrain from using plastic bags at a grocery store (Rubens et al. 2015). Mixed results were found for norms and salience. Communicating social norms reduced plastic bag use and buffet food waste, but no effect was detected on reducing paper waste. Salience had an effect on opting out of receiving junk mail but not refusing plastic bags for groceries (Hamann et al. 2015; Rubens et al. 2015).

Traditional interventions changed behavior in this domain. Financial incentives and education were effective in reducing junk mail and plastic waste (Rommel et al. 2015; Santos and van der Linden 2016).

\section{Water use}

Commitments and norms showed an effect on reducing water consumption by households, students, and hotel guests. Interventions employing commitments were effective nine of the 10 times they were tested, particularly those encouraging hotel guests to reuse towels (Baca-Motes et al. 2013). Targeting norms by exposing participants to messages about the water-saving behavior of their peers also reduced water use, and increased both towel reuse and participation in conservation programs (Goldstein et al. 2008; Ferraro and Price 2013; Brent et al. 2015). Making personal identity salient had mixed effects on water use but simple reminders proved effective: water use was $23 \%$ lower in households in which water-use labels were attached to showers and appliances than in households that received the same information via leaflets (Kurz et al. 2005). 
Table 2. Balance of evidence to change environmentally relevant behaviors

\begin{tabular}{|c|c|c|c|}
\hline Intervention & Promising & Mixed & No effect \\
\hline \multicolumn{4}{|c|}{ Commitments } \\
\hline \multicolumn{4}{|l|}{ Defaults } \\
\hline \multicolumn{4}{|l|}{ Messenger } \\
\hline \multicolumn{4}{|l|}{ Norms } \\
\hline \multicolumn{4}{|l|}{ Priming } \\
\hline \multicolumn{4}{|l|}{ Salience } \\
\hline \multicolumn{4}{|l|}{ Education } \\
\hline \multicolumn{4}{|l|}{ Financial } \\
\hline \multicolumn{4}{|c|}{$\begin{array}{l}\text { Notes. family planning; }=\text { land management; }=\text { meat consumption; }=\text { transportation choices; }=\text { waste production; } \\
\text { significant effect of that intervention, as reported by the studies' authors. Promising }=75 \% \text { or more results found an effect; Mixed }=\text { less than } \\
75 \% \text { but more than zero results; No effect }=\text { none of the studies that tested that intervention detected an effect. See Figure } 4 \text { for the relative } \\
\text { frequency of tested interventions within each domain. }\end{array}$} \\
\hline
\end{tabular}

Education and financial incentives showed mixed results, leading to lower water use in some cases but not others.

\section{What we know about contextual interventions}

Experimental evidence suggests that the use of behavioral insights may alter environmentally relevant behaviors (Table 2). Interventions aimed at affecting norms or defaults produced consistent effects on behaviors across multiple studies and domains. Several large-scale field experiments demonstrated that normative messages reduced household water consumption by $2.5-7.7 \%$ compared to control groups who did not receive the contextual intervention (Ferraro and Price 2013; Brent et al. 2015; Datta et al. 2015). Switching default buffet plate size, printer settings, menu offerings, and costshare baseline amounts made it easier for individuals to act in a pro-environmental manner.

The evidence for the effects of commitments and salience is less straightforward. Although commitments to reuse towels and to reduce waste and meat consumption were effective, no effect was found on reducing driving or adopting land conservation practices. Reminders to change behavior had an effect on water consumption but not on taking daily contraception or reducing plastic bag use at the supermarket. Reminders about financial benefits did not increase pro-environmental behavior more than facts alone, and actually had a negative effect compared to reminders about environmental benefits. Priming and messenger effects were each only tested in one study. 


\section{- Contextual interventions in practice}

Overall, contextual interventions outperform education interventions. Six studies that compared contextual interventions directly against an education intervention and a no-intervention control reported that the contextual intervention produced the largest gain in proenvironmental behavior (Ferraro and Price 2013; Campbell-Arvai et al. 2014; Rommel et al. 2015). Financial incentives also outperformed education interventions. However, it is less clear how contextual interventions compared to financial incentives. The two may be substitutes, with one being more effective than the other in certain instances. Or they may be complementary: appropriately tailored contextual interventions may optimize the acceptability and impact of financial incentives.

Indeed, our findings indicated that some interventions work best in combination. Several family planning studies showed education interventions to be most effective when combined with health visits, vocational training, or social networking (Chong et al. 2013; Ahmed et al. 2015; Bandiera et al. 2015). A number of studies combined multiple interventions into a single treatment, making it difficult to discern the causal effects of any one intervention or their interactions.

The effectiveness of contextual interventions is often conditional on who receives the intervention and in what context. Whereas targeting norms reduced water consumption, effects were repeatedly moderated by other factors such as delivery method, baseline water use, and socioeconomic status. Communication of norms also influenced family planning behavior, but gains in contraception use were offset by a negative effect on women's subjective well-being. These caveats illustrate an important limitation of behavioral interventions: because their success is often conditional on prior beliefs, characteristics, and context, the development of universally effective solutions is unlikely. Accounting for such complexity may require combinations of interventions that target both deliberative and subconscious thought to change behaviors (van der Linden 2013).

\section{Future research and program design}

Our review identified four areas where additional research could yield guidance for policy making that encourages pro-environmental behavior changes.

\section{Test interventions in domains that have the greatest impact on the environment}

Meat consumption, unsustainable land management, and population growth put considerable stress on the environment (Wynes and Nicholas 2017), yet we could find only four, seven, and nine studies, respectively, that tested behavior changes in these domains. More experimental research on reducing meat consumption, for example, could slow the rate of land conversion (Foley et al. 2011), and lower greenhouse-gas emissions (Garnett 2011) and biodiversity loss across land- and seascapes (Machovina et al. 2015). Future research should also target producer behavior. Whereas financial incentives and regulation will remain important tools for influencing corporate decisions, contextual interventions may encourage low-cost, potentially high-benefit behavioral changes that are good for the environment.

\section{Test interventions that have not been well examined with respect to pro-environmental behaviors}

More research on messenger effects could be useful to environmental programs and policy makers. Given the strength of these factors in influencing health behaviors and charitable donations (Durantini et al. 2006; Landry et al. 2006), such interventions may prove to be important tools for conservation.

\section{Test interventions using randomized controlled designs of adequate size}

Well-designed experiments allow us to determine causeand-effect relationships between interventions and desired environmental outcomes, yet many proenvironmental behavior-change studies are poorly designed, lacking adequate controls and randomization (Frederiks et al. 2016). Fewer than 10\% of the studies in our literature review explicitly discussed the statistical power of their results, and given that nearly one-quarter of the studies we reviewed had sample sizes of fewer than 100 participants, many results are likely underpowered. Studies involving appropriate experimental designs and sufficient sample sizes will allow us to draw stronger conclusions about the causal effects and magnitude of behavior-change interventions.

\section{Evaluate conditions, cost-effectiveness, and persistence of behavior-change interventions}

In order to translate experimental evidence into environmental policy, more research is required to understand the contexts in which certain interventions work, at what cost, and for how long. There are roadmaps for implementation (see Clayton et al. 2013; Reddy et al. 2017), but little is known about the combinations and moderators of interventions that will determine their relevance to policy. A meta-analysis on commitments similarly highlights a lack of empirical evidence explaining why and under what conditions a given intervention will be effective (Lokhorst et al. 2013). Although advocates of contextual interventions highlight their low cost (Benartzi et al. 2017), only 15 of the 72 studies included in our review addressed the cost-effectiveness of the tested interventions. Twenty studies considered 
the duration of behavior change, but only nine measured the effect beyond 6 months. If the effects of promising interventions expire with the end of their implementation, there is little hope for addressing the scale of current environmental challenges (van der Linden 2015). Future experiments should prioritize evidence on the net value of the behavioral insight and the persistence of the behavioral changes even after the interventions are no longer being implemented.

\section{Looking ahead}

Behavioral insights show promise for sustainability, but much work remains to make them actionable for environmental policy design and program implementation. We encourage collaboration between scholars and practitioners to embed tests of behavioral interventions within existing environmental programs, given that such tests provide both generalizable scientific knowledge and specific applications that can be incorporated into scaled-up programs. A variety of researcher-practitioner collaborations are doing just this for programs in poverty alleviation, public health, criminal justice, tax compliance, and education. Similar efforts have begun to address environmental challenges. Our review suggests that there is both a need and an opportunity to build an evidence base of behavioral insights tailored to achieving sustainability goals.

\section{Acknowledgements}

We thank S Flint and D Fredman for helpful comments and contributions, which greatly improved this manuscript; the Gund Institute for Environment for their Collaboration Grant to BF, which made this work possible; and the University of Vermont's James Marsh Professor-at-Large and Burack Distinguished Lecture Series for supporting SP and AB, respectively.

\section{References}

Abrahamse W and Steg L. 2013. Social influence approaches to encourage resource conservation: a meta-analysis. Global Environ Chang 23: 1773-85.

Abrahamse W, Steg L, Vlek C, and Rothengatter T. 2005. A review of intervention studies aimed at household energy conservation. J Environ Psychol 25: 273-91.

Ahmed S, Ahmed S, McKaig C, et al. 2015. The effect of integrating family planning with a maternal and newborn health program on postpartum contraceptive use and optimal birth spacing in rural Bangladesh. Stud Family Plann 46: 297-312.

Andrews AC, Clawson RA, Gramig BM, and Raymond L. 2013. Why do farmers adopt conservation tillage? An experimental investigation of framing effects. J Soil Water Conserv 68: 501-11.

Ashraf N, Field E, and Lee J. 2014. Household bargaining and excess fertility: an experimental study in Zambia. Am Econ Rev 104: 2210-37.

Baca-Motes K, Brown A, Gneezy A, et al. 2013. Commitment and behavior change: evidence from the field. J Consum Res 39: 1070-84.

Bandiera O, Burgess R, Goldstein M, et al. 2015. Women's empowerment in action: evidence from a randomized control trial in
Africa. London, UK: The London School of Economics and Political Science, Suntory and Toyota International Centres for Economics and Related Disciplines.

Benartzi S, Beshears J, Milkman KL, et al. 2017. Should governments invest more in nudging? Psychol Sci 28: 1041-55.

Bolderdijk JW, Steg L, Geller ES, et al. 2013. Comparing the effectiveness of monetary versus moral motives in environmental campaigning. Nat Clim Change 3: 413-16.

Brent DA, Cook JH, and Olsen S. 2015. Social comparisons, household water use, and participation in utility conservation programs: evidence from three randomized trials. J Assoc Environ Resource Econ 2: 597-627.

Campbell-Arvai V and Arvai J. 2015. The promise of asymmetric interventions for addressing risks to environmental systems. Environ Systems Decisions 35: 472-82.

Campbell-Arvai V, Arvai J, and Kalof L. 2014. Motivating sustainable food choices: the role of nudges, value orientation, and information provision. Environ Behav 46: 453-75.

Chong A, Gonzalez-Navarro M, Karlan D, and Valdivia M. 2013. Effectiveness and spillovers of online sex education: evidence from a randomized evaluation in Colombian public schools. Cambridge, MA: National Bureau of Economic Research.

Clayton S, Litchfield C, and Geller ES. 2013. Psychological science, conservation, and environmental sustainability. Front Ecol Environ 11: 377-82.

Cowling RM. 2014. Let's get serious about human behavior and conservation. Conserv Lett 7: 147-48.

Datta S, Miranda JJ, Zoratto LDC, et al. 2015. A behavioral approach to water conservation: evidence from Costa Rica. Washington, DC: The World Bank.

Delmas MA, Fischlein M, and Asensio OI. 2013. Information strategies and energy conservation behavior: a meta-analysis of experimental studies from 1975 to 2012. Energ Policy 61: 729-39.

Desai J and Tarozzi A. 2011. Microcredit, family planning programs, and contraceptive behavior: evidence from a field experiment in Ethiopia. Demography 48: 749-82.

Dietz T. 2014. Understanding environmentally significant consumption. P Natl Acad Sci USA 111: 5067-68.

Dolan P, Hallsworth M, Halpern D, et al. 2012. Influencing behaviour: the mindspace way. J Econ Psychol 33: 264-77.

Downs JS, Loewenstein G, and Wisdom J. 2009. Strategies for promoting healthier food choices. Am Econ Rev 99: 159-64.

Durantini MR, Albarracín D, Mitchell AL, et al. 2006. Conceptualizing the influence of social agents of behavior change: a meta-analysis of the effectiveness of HIV-prevention interventionists for different groups. Psychol Bull 132: 212-48.

Egebark J and Ekström M. 2016. Can indifference make the world greener? J Environ Econ Manag 76: 1-13.

Ferrara I and Serrat Y. 2008. Household behaviour and the environment: reviewing the evidence. Paris, France: Organisation for Economic Co-operation and Development.

Ferraro PJ and Price MK. 2013. Using nonpecuniary strategies to influence behavior: evidence from a large-scale field experiment. Rev Econ Stat 95: 64-73.

Fischer J, Dyball R, Fazey I, et al. 2012. Human behavior and sustainability. Front Ecol Environ 10: 153-60.

Foley JA, DeFries R, Asner GP, et al. 2005. Global consequences of land use. Science 309: 570-74.

Foley JA, Ramankutty N, Brauman KA, et al. 2011. Solutions for a cultivated planet. Nature 478: 337-42.

Frederiks ER, Stenner K, Hobman EV, and Fischle M. 2016. Evaluating energy behavior change programs using randomized controlled trials: best practice guidelines for policymakers. Energy Res Soc Sci 22: 147-64.

Garnett T. 2011. Where are the best opportunities for reducing greenhouse gas emissions in the food system (including the food chain)? Food Policy 36: S23-32. 
Goldstein NJ, Cialdini RB, and Griskevicius V. 2008. A room with a viewpoint: using social norms to motivate environmental conservation in hotels. J Consum Res 35: 472-82.

Gould RK, Ardoin NM, Biggar M, et al. 2016. Environmental behavior's dirty secret: the prevalence of waste management in discussions of environmental concern and action. Environ Manage 58: 268-82.

Hamann KRS, Reese G, Seewald D, and Loeschinger DC. 2015. Affixing the theory of normative conduct (to your mailbox): injunctive and descriptive norms as predictors of anti-ads sticker use. J Environ Psychol 44: 1-9.

Hou MY, Hurwitz S, Kavanagh E, et al. 2010. Using daily textmessage reminders to improve adherence with oral contraceptives: a randomized controlled trial. Obstet Gynecol 116: 633-40.

IPCC (Intergovernmental Panel on Climate Change). 2014. Climate change 2014: mitigation of climate change. Contribution of Working Group III to the Fifth Assessment Report of the Intergovernmental Panel on Climate Change. Cambridge, UK, and New York, NY: Cambridge University Press.

Jayachandran S, de Laat J, Lambin EF, and Stanton CY. 2016. Cash for carbon: a randomized controlled trial of payments for ecosystem services to reduce deforestation. Cambridge, MA: National Bureau of Economic Research.

Johnson EJ and Goldstein D. 2003. Do defaults save lives? Science 302: $1338-39$

Kahneman D, Knetsch JL, and Thaler RH. 1991. Anomalies: the endowment effect, loss aversion, and status quo bias. J Econ Perspect 5: 193-206.

Kallbekken S and Sælen H. 2013. "Nudging” hotel guests to reduce food waste as a win-win environmental measure. Econ Lett 119: 325-27.

Kamenica E. 2012. Behavioral economics and psychology of incentives. Annu Rev Econ 4: 427-52.

Karlin B, Zinger JF, and Ford R. 2015. The effects of feedback on energy conservation: a meta-analysis. Psychol Bull 141: $1205-27$.

Katzev R and Bachman W. 1982. Effects of deferred payment and fare manipulations on urban bus ridership. J Appl Psychol 67: 83-88.

Kerr J, Vardhan M, and Jindal R. 2012. Prosocial behavior and incentives: evidence from field experiments in rural Mexico and Tanzania. Ecol Econ 73: 220-27.

Kirakozian A. 2016. One without the other? Behavioural and incentive policies for household waste management. J Econ Surv 30: 526-51.

Kondylis F, Mueller V, Sheriff G, and Zhu S. 2016. Do female instructors reduce gender bias in diffusion of sustainable land management techniques? Experimental evidence from Mozambique. World Dev 78: 436-49.

Kurz T, Donaghue N, and Walker I. 2005. Utilizing a social-ecological framework to promote water and energy conservation: a field experiment. J Appl Soc Psychol 35: 1281-300.

Landry CE, Lange A, List JA, et al. 2006. Toward an understanding of the economics of charity: evidence from a field experiment. Q J Econ 121: 747-82.

Lokhorst AM, van Dijk J, Staats H, et al. 2010. Using tailored information and public commitment to improve the environmental quality of farm lands: an example from the Netherlands. Hum Ecol 38: 113-22.

Lokhorst AM, Werner C, Staats H, et al. 2013. Commitment and behavior change: a meta-analysis and critical review of commitment-making strategies in environmental research. Environ Behav 45: 3-34.

Loy LS, Wieber F, Gollwitzer PM, and Oettingen G. 2016. Supporting sustainable food consumption: mental contrasting with implementation intentions (MCII) aligns intentions and behavior. Front Psychol 7: 607.
Machovina B, Feeley KJ, and Ripple WJ. 2015. Biodiversity conservation: the key is reducing meat consumption. Sci Total Environ 536: 419-31.

Maki A, Burns RJ, Ha L, and Rothman AJ. 2016. Paying people to protect the environment: a meta-analysis of financial incentive interventions to promote proenvironmental behaviors. J Environ Psychol 47: 242-55.

Messer KD, Ferraro PJ, and Allen W. 2016. Behavioral nudges in competitive environments: a field experiment examining defaults and social comparisons in a conservation contract auction. Newark, DE: University of Delaware.

Monroe JT, Lofgren IE, Sartini BL, and Greene GW. 2015. The Green Eating Project: web-based intervention to promote environmentally conscious eating behaviours in US university students. Public Health Nutr 18: 2368-78.

Mwaikambo L, Speizer IS, Schurmann A, et al. 2011. What works in family planning interventions: a systematic review. Stud Family Plann 42: 67-82.

Nyborg K, Anderies JM, Dannenberg A, et al. 2016. Social norms as solutions. Science 354: 42-43.

Osbaldiston R and Schott JP. 2012. Environmental sustainability and behavioral science: meta-analysis of proenvironmental behavior experiments. Environ Behav 44: 257-99.

Ostrom E. 2000. Collective action and the evolution of social norms. J Econ Perspect 14: 137-58.

Reddy SMW, Montambault J, Masuda YJ, et al. 2017. Advancing conservation by understanding and influencing human behavior. Conserv Lett 10: 248-56.

Rommel J, Buttmann V, Liebig G, et al. 2015. Motivation crowding theory and pro-environmental behavior: experimental evidence. Econ Lett 129: 42-44.

Rubens L, Gosling P, Bonaiuto M, et al. 2015. Being a hypocrite or committed while I am shopping? A comparison of the impact of two interventions on environmentally friendly behavior. Environ Behav 47: 3-16.

Santos JM and van der Linden S. 2016. Changing norms by changing behavior: the Princeton drink local program. Environ Practice 18: 116-22.

Schultz PW, Oskamp S, and Mainieri T. 1995. Who recycles and when? A review of personal and situational factors. J Environ Psychol 15: 105-21.

Simon HA. 1955. A behavioral model of rational choice. Q J Econ 69: 99-118.

Thaler RH and Benartzi S. 2004. Save More Tomorrow ${ }^{\mathrm{TM}}$ : using behavioral economics to increase employee saving. J Polit Econ 112: S164-87.

Tversky A and Kahneman D. 1974. Judgment under uncertainty: heuristics and biases. Science 185: 1124-31.

van der Linden S. 2013. A response to Dolan. In: Oliver AJ (Ed). Behavioural public policy. Cambridge, UK: Cambridge University Press.

Volpp KG, Asch DA, Galvin R, and Loewenstein G. 2011. Redesigning employee health incentives - lessons from behavioral economics. New Engl J Med 365: 388-90.

Wada Y and Bierkens MFP. 2014. Sustainability of global water use: past reconstruction and future projections. Environ Res Lett 9: 104003.

Wynes S and Nicholas KA. 2017. The climate mitigation gap: education and government recommendations miss the most effective individual actions. Environ Res Lett 12: 074024.

\section{- Supporting Information}

Additional, web-only material may be found in the online version of this article at http://onlinelibrary. wiley.com/doi/10.1002/fee.1777/suppinfo 
Copyright of Frontiers in Ecology \& the Environment is the property of John Wiley \& Sons, Inc. and its content may not be copied or emailed to multiple sites or posted to a listserv without the copyright holder's express written permission. However, users may print, download, or email articles for individual use. 